\title{
Analisis Faktor-faktor yang Mempengaruhi Kepuasan Pelanggan di Indomaret Hayam Wuruk Purwodadi
}

\author{
AKHMAD NURROFI \\ Jurusan Manajemen Sekolah Tinggi Ilmu Ekonomi Anindyaguna Semarang \\ Jl. Tentara Pelajar No.49, Jomblang, Kec. Candisari, \\ Kota Semarang, Jawa Tengah 50256 \\ Email : akhmadsantoso71@yahoo.co.id
}

Diterima 3 Agustus 2021; disetujui 21 Agustus 2021;

\begin{abstract}
Abstrak. This study aims to test and analyze the effect of company image, price perception and service quality on consumer satisfaction, case study at Indomaret Minimarket Jl. Hayam Wuruk Purwodadi. Data collection is done through distributing questionnaires to 115 consumers. Data analysis in this study using SPSS version 21. The sampling technique used is the census method and the data testing techniques used in this study include the validity test with factor analysis, test reliability with Cronbach Alpha. Classical assumption tests and multiple linear regression analysis, to test and prove the research hypothesis. The results of the analysis show that the first equation is $Y=$ $0.254 X 1+0.029 X 2+0.551 X 3$ which means the variable company image, service quality has a positive effect on the variable customer satisfaction, while the price perception does not affect consumer satisfaction.
\end{abstract}

Keywords: Corporate Image, Product Price Perception, Service Quality and Consumer Satisfaction.

\section{PENDAHULUAN}

Dalam dunia bisnis minimarket semakin persaingannya semakin kompetitif, untuk memenangkan persaingan tersebut perlu adanya peningkatan dari berbagai macam langkah yang harus dilaksanakan oleh pemangku kepentingan, dimana pemangku kepentingan harus mampu untuk menjangkau ke semua tempat yang paling dekat dengan konsumen. Kenyamanan merupakan faktor penting agar pelanggan segera dapat menikmati barang yang paling mudah dijangkau secara cepat. Pelayanan toko-toko pengecer yang menawarkan berbagai macam atribut dan fasilitasnya dengan tujuan menarik perhatian konsumen untuk berbelanja secara langsung semakin meningkatkan persaingan tajam pada industri retail. Industri retail dituntut untuk memberikan berbagai macam atribut penawaran kepada pelanggan dimana pelanggan mempunyai bergaining power yang kuat untuk memilih pengecer yang memberikan keuntungan banyak. Maka dari itu produsen harus bisa menciptakan kepuasan pada konsumen melalui strategi pemasaran yang baik.

Dengan adanya persaingan sesama produk maka citra sebagai salah satu penunjang perusahaan untuk menarik perhatian pelanggan harus sangat diperhatikan. Perusahaan harus bekerja keras dalam membangun citra di mata masyarakat luas. Citra sangat diperlukan dalam strategi pemasaran yang akan merangsang perilaku pembelian. Sebuah supermarket/pasar swalayan/perusahaan ataupun produk/jasa yang terusmenerus memegang citra baik pada masyarakat akan mendapatkan posisi yang lebih baik di pasar, keunggulan kompetitif yang 
berkelanjutan, meningkatkan pangsa pasar dan kinerja (Stephen, et al 2007).

Harga yang terjangkau dan kualitas yang baik memungkinkan adanya kepuasan konsumen dan akan menarik konsumen baru sehingga diharapkan akan membuat konsumen loyal pada akhirnya. Kotler dan Amstrong (2001), harga merupakan sejumlah uang yang dibebankan atas suatu produk atau jumlah dari seluruh nilai yang ditukarkan oleh konsumen atau manfaat karena menggunakan produk atau jasa tersebut. Pelaku usaha berusaha untuk menetapkan harga yang terjangkau agar konsumen merasa puas dengan harga yang telah ditetapkan oleh pelaku usaha. Pelaku usaha biasanya dalam menetapkan harga sesuai dengan perekonomian konsumen, berharap agar semua konsumen dapat membeli barang dan jasa yang telah ditawarkan. Dari sudut pandang konsumen, harga sering digunakan sebagai indikator nilai bilamana harga tersebut dihubungkan dengan manfaat yang dirasakan atas barang/jasa yang dikonsumsi konsumen.

Kualitas pelayanan/service quality adalah pemenuhan kebutuhan dan keinginan pelanggan serta ketepatan penyampaiannya untuk mengimbangi harapan pelanggan (Tjiptono, 2002). Dengan demikian, ada dua faktor utama yang mempengaruhi kualitas jasa yaitu jasa yang diharapkan (expected service) dan jasa yang dirasakan/dipersepsikan (perceived service). Suatu pelayanan dapat dikatakan berkualitas apabila pelayanan tersebut memenuhi harapan/ekspektasi dan kebutuhan pelanggan. Kualitas pelayanan adalah unsur penentu dalam perusahaan untuk mewujudkan kepuasan konsumen dan mempertahankan konsumen. Kualitas pelayanan sebagai usaha untuk mewujudkan kenyamanan terhadap konsumen agar konsumen merasa mempunyai nilai yang lebih dari yang diharapkan.

Dari peneliti terdahulu yang di lakukan oleh Saputra et al (2015), Tjahjaningsih (2013), Gulla. et al (2015), menyatakan bahwa untuk penelitian men-datang masih memungkinkan menambah determinan lain untuk menjelaskan kepu-asan pelanggan, misalnya persepsi harga produk dan kualitas layanan. Dari saran yang di berikan oleh penelitian terdahulu, maka peneliti menambahkan variabel per-sepsi harga dan kualitas pelayanan sebagai faktor yang mempengaruhi kepuasan kon-sumen sebagaimana yang telah disarankan peneliti terdahulu. Berdasarkan latar bela-kang diatas penulis bertujuan meneliti pe-ngaruh citra perusahaan, persepsi harga produk, kualitas pelayanan terhadap ke-puasan konsumen.

\section{TINJAUAN TEORETIS}

Kepuasan Konsumen. Menurut Giese dan Cote (2000) meskipun terdapat banyaknya mengenai definisi kepuasan konsumen, akan tetapi secara umum terdapat tiga komponen utama, yaitu: (a) respon : tipe dan intensitas kepuasan konsumen merupakan respon emosional dan juga kognitif. Intensitas responnya mulai dari sangat puas dan menyukai produk sampai sikap yang apatis terhadap produk tertentu; (b) Fokus pada performansi objek disesuaikan pada beberapa standar. Nilai standar ini secara langsung berhubungan dengan produk, konsumsi, keputusan berbelanja, penjual dan toko; (c) Waktu respon terjadi pada waktu tertentu, antara lain : setelah konsumsi, setelah pemilihan produk atau jasa, berdasarkan pengalaman akumulatif. Durasi kepuasan mengarah kepada berapa lama respon kepuasan itu berakhir.

Citra Perusahaan. Citra adalah bagaimana pihak lain memandang sebuah perusahaan, seseorang, suatu komite atau suatu aktivitas. Tugas perusahaan dalam membentuk citranya adalah dengan mengidentifikasi citra seperti apa yang ingin dibentuk di mata publik atau masyarakatnya. Citra adalah sebuah cerminan dari identitas sebuah organisasi atau perusahaan. Sebuah 
organisasi atau perusahaan dapat memiliki beberapa citra yang berbeda-beda di mata publik yang berbeda-beda pula. Namun, seberapa samar-samarnya sebuah citra, citra merupakan realitas karena orang hanya dapat bereaksi terhadap apa yang telah mereka alami dan rasakan. Kotler (2007) menyatakan bahwa citra korporasi dapat sangat spesifik atau sangat berlebihan dan bahwa beberapa organisasi mungkin tidak ingin atau tidak memerlukan citra yang spesifik.

Kotler (2009) menjelaskan pengertian citra adalah persepsi masyarakat terhadap perusahaan atau produknya. Citra dipengaruhi oleh banyak faktor di luar kontrol perusahaan. Menurut Jasfar (2005), citra suatu perusahaan yang meliputi nama baik perusahaan, reputasi ataupun keahliannya merupakan faktor yang sering mempengaruhi keputusan pembeli dan sektor jasa dibandingkan sektor produk.

Persepsi Harga. Konsumen merupakan individu dengan karakteristik yang berbedabeda. Penilaian yang dirasakan setiap konsumen terhadap suatu produk maupun jasa yang mereka terima tidak sama. Persepsi konsumen terhadap suatu harga dapat mempengaruhi keputusannya dalam membeli suatu produk sehingga suatu perusahaan harus mampu memberikan persepsi yang baik terhadap produk atau jasa yang mereka jual. Menurut Schiffman \& Kanuk (2007) persepsi adalah suatu proses seorang individu dalam menyeleksi, mengorganisasikan, dan menerjemahkan stimulus-stimulus informasi yang datang menjadi suatu gambaran yang menyeluruh. Persepsi mempunyai pengaruh yang kuat bagi konsumen. Salah satu faktor yang berpengaruh terhadap konsumen yaitu persepsi akan harga.

Menurut Hawkins, Nothesbaugh dan Best (2007), persepsi adalah "Sebuah proses yang diawali dengan pemaparan konsumen dan perhatian terhadap rangsangan pemasaran dan berakhir dengan penafsiran oleh konsumen". Sementara menurut Rangkuti (2008), persepsi harga adalah biaya relatif yang harus konsumen keluarkan untuk memperoleh produk atau jasa yang ia inginkan. Sedangkan menurut Peter dan Olson (2008), persepsi harga berkaitan dengan bagaimana informasi harga dipahami seluruhnya oleh konsumen dan memberikan makna yang dalam bagi mereka. Pada saat konsumen melakukan evaluasi dan penelitian terhadap harga dari suatu produk sangat dipengaruhi oleh perilaku dari konsumen itu sendiri.

Harga merupakan salah satu atribut penting yang dievaluasi oleh konsumen sehingga manajer perusahaan perlu benarbenar memahami peran tersebut dalam mempengaruhi sikap konsumen. Harga sebagai atribut dapat diartikan bahwa harga merupakan konsep keanekaragaman yang memiliki arti berbeda bagi tiap konsumen, tergantung karakteristik konsumen, situasi dan produk (Mowen dan Minor, 2002). Dengan kata lain, pada tingkat harga tertentu yang telah dikeluarkan, konsumen dapat merasakan manfaat dari produk yang telah dibelinya dan konsumen akan merasa puas apabila manfaat yang mereka dapatkan sebanding atau bahkan lebih tinggi dari nominal uang yang mereka keluarkan.

Harga adalah sejumlah uang yang ditukarkan untuk sebuah produk atau jasa. Lebih jauh lagi, harga adalah sejumlah nilai yang konsumen tukarkan untuk jumlah manfaat dengan memiliki atau menggunakan suatu barang atau jasa (Kotler, 2001). Harga merupakan hal yang diperhatikan konsumen saat melakukan pembelian. Sebagian konsumen bahkan mengidentifikasikan harga dengan nilai. Harga merupakan sejumlah uang (ditambah beberapa barang kalau mungkin) yang dibutuhkan untuk mendapatkan sejumlah kombinasi dari barang beserta pelayanannya (Swasta, 2001).

Kualitas Pelayanan. Kualitas merupakan suatu faktor penting yang diberikan perusahaan untuk para konsumennya. Menurut Mowen (2002) unsur yang paling penting dalam suatu produk atau jasa adalah kualitas yang tinggi yang dikendalikan oleh konsumen, karena itu perusahaan harus 


\section{Gambar 1 \\ Kerangka Pemikiran Teoritis}

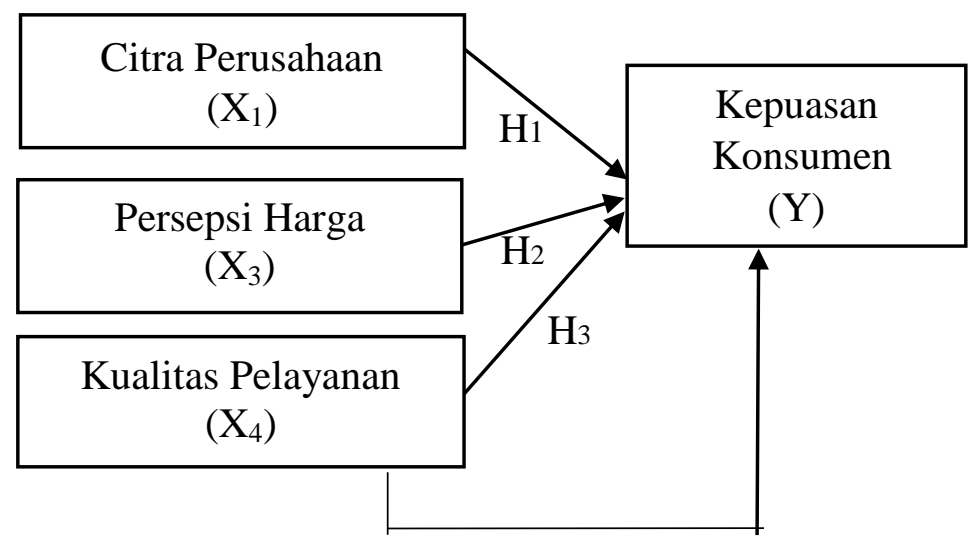

Sumber: Maryati, (2020), Saputra (2015) dan Gulla (2015)

menilai persepsi konsumen atas kualitas.

Definisi pelayanan menurut Supranto (2011) pelayanan merupakan suatu kinerja penampilan, tidak berwujud dan cepat hilang, lebih dapat dirasakan dari pada dimiliki, serta konsumen lebih dapat berpartisipasi aktif dalam proses mengkonsumsi jasa tersebut. Kualitas pelayanan adalah suatu instrumen dan strategi yang diberikan perusahaan untuk menarik minat konsumen untuk mengkonsumsi produk atau jasa yang diberikan, umumnya konsumen yang mengkonsumsi produk atau jasa, konsumen melihat dari kualitas yang diberikan serta pelayanannya, apabila kualitas pelayanan tersebut memuaskan konsumen akan timbul merasa keinginan yang mereka harapkan tercapai sehingga muncul perasaan puas akan produk atau jasa tersebut.

Hipotesis Penelitian. Adapun hipotesis yang dapat dirumuskan dalam penelitian ini

Pengaruh Citra Perusahaan Terhadap Kepuasan Konsumen. Penelitian yang di lakukan oleh Maryati (2020) menyatakan bahwa citra berpengaruh positif signifikan terhadap kepuasan pelanggan. Penelitian lain yang dilakukan oleh Atmaja (2016) menyatakan bahwa citra perusahaan mempunyai pengaruh signifikan terhadap kepuasan pelanggan.
Terdapat pengaruh positif dan signifikan antara citra perusahaan terhadap kepuasan pelanggan (Suratno, at. al, 2016). Dari beberapa hasil penelitian di atas maka peneliti mengajukan hipotesis sebagai berikut :

H1 : Citra perusahaan berpengaruh terhadap kepuasan konsumen

Pengaruh Persepsi Harga Terhadap Kepuasan Konsumen. Penelitian yang di lakukan oleh Wijaya dan Karneli (2017) menyatakan bahwa harga secara parsial berpengaruh positif dan signifikan terhadap kepuasan pelanggan. Penelitian lain yang di lakukan oleh Rendy Gulla et al, (2015) menyatakan bahwa harga secara parsial berpengaruh signifikan terhadap kepuasan konsumen. Menurut Wardani et al, (2016) menyatakan bahwa terdapat pengaruh positif dan signifikan harga terhadap kepuasan konsumen. Dari beberapa peneliti di atas maka peneliti mengajukan hipotesis sebagai berikut:

$\mathrm{H} 2$ : Persepsi harga berpengaruh terhadap kepuasan konsumen

Pengaruh Kualitas Pelayanan Terhadap Kepuasan Konsumen. Penelitian yang di lakukan oleh Jimanto dan Kunto (2014) menyatakan bahwa variabel kualitas pelayanan berpengaruh positif terhadap kepuasan konsumen. Variabel 
kualitas pelayanan mempunyai pengaruh positif dan signifikan terhadap variabel kepuasan pelanggan Nuruddin, (2021). Penelitian lain yang dilakukan oleh Oktaviani et al, (2021) menyatakan bahwa kualitas pelayanan berpengaruh positif dan signifikan terhadap kepuasan konsumen. Dari beberapa hasil penelitian di atas maka peneliti mengajukan hipotesis sebagai berikut:

H3 : Kualitas pelayanan berpengaruh terhadap kepuasan konsumen

\section{METODE PENELITIAN}

Lokasi Penelitian. Lokasi penelitian ini dilakukan di Alfa Mart Jl. Hayam Wuruk Purwodadi.

Jenis Penelitian. Jenis penelitian yang digunakan dalam penelitian ini adalah penelitian Asosiatif dan didalamnya diharapkan dapat diberikan penjelasan mengenai pengaruh antar variable penelitian. (Kotler dan Amstrong, 2008) menyatakan bahwa penelitian asosiatif merupakan penelitian yang bertujuan untuk mengetahui hubungan antara dua variable atau lebih.

Variabel terikat (dependent variable) Y menurut Kuncoro (2009) variabel independen yaitu variabel yang menjadi perhatian utama dalam sebuah pengamatan, variabel independen dalam penelitian ini adalah kepuasan konsumen.

\section{Variabel bebas (independent variable)}

$X$ menurut Kuncoro (2009) variabel independen yaitu variabel yang dapat mempengaruhi perubahan dalam variabel dependen dan mempunyai hubungan yang positif ataupun yang negatif bagi variabel dependen. Dalam penelitian ini variabel independennya yaitu citra perusahaan $\left(\mathrm{X}_{1}\right)$, persepsi harga $\left(\mathrm{X}_{2}\right)$, dan kualitas pelayanan $\left(\left(\mathrm{X}_{3}\right)\right.$.

Citra Perusahaan yaitu kesan secara umum yang tertinggal di benak pelanggan sebagai hasil dari kumpulan perasaan, ide, sikap dan pengalaman dengan perusahaan yang disimpan dalam ingatan. Kesan tersebut kemudian diubah bentuknya menjadi citra positif atau negatif sesuai dengan perasaan dan pengalaman, dengan indikator : a. Reputation/ reputasi perusahaan. b. Percaya bahwa perusahaan selama ini baik. c. Value / nilai-nilai yang dimiliki suatu perusahaan. d. Lokasi minimarket Suratno, et al (2016)

Persepsi harga berkaitan dengan bagaimana informasi harga dipahami seluruhnya oleh konsumen dan memberikan makna yang dalam bagi mereka, Peter dan Olson (2008), dengan indikator sebagai berikut : a. Keterjangkauan harga produk (jasa) b. Kesesuaian harga dengan kualitas produk (jasa) c. Daya saing harga produk (jasa) d. Kesesuaian harga dengan manfaat. Saputra. at al (2016)

Kualitas pelayanan adalah tingkat keunggulan yang diharapkan dan pengendalian atas tingkat keunggulan tersebut untuk memenuhi keinginan pelanggan. Dengan indikator a. Tangible (berwujud), b. Empathy (peduli), c. Responsiviness (ketanggapan), d. Assurance (jaminan) Saputra., et al (2016)

Kepuasan konsumen sebagai evaluasi yang memberikan hasil dimana pengalaman yang dirasakan setidaknya sama baiknya atau sesuai dengan yang diharapkan (Tjiptono, 2010) dengan indikator a) Terpenuhinya harapan pelanggan, b) Perasaan puas menggunakan produk (jasa), c) Kepuasan dengan pelayanan, d) Kepuasan secara keseluruhan Suratno, at al (2017)

Populasi Penelitian. Dalam penelitian ini yang menjadi populasi adalah konsumen atau pelanggan yang pernah berbelanja di Indomaret Jl.Hayam Wuruk Purwodadi dalam penelitian ini tidak diketahui. Mengingat populasi tidak didapat ditentukan secara tepat maka untuk menentukan jumlah sampel, menurut Rao (2011) menggunakan rumus sebagai berikut :

$$
\boldsymbol{n}=\frac{Z^{2}}{4(\mathrm{moe})^{2}}
$$

Keterangan :

$n \quad:$ Besar sampel

$Z$ : Didapat dari nilai $\mathrm{z}$ pada tabel distribusi yaitu $1.7 \times 0.010 Z=1,71$ 
Moe : Margin of error atau kesalahan maksimum yang bisa ditoleransi biasanya $10 \%$ atau 0,1

Dengan dasar tersebut maka dapat dilihat ukuran sampel minimal yang harus dicapai dalam peneliti ini adalah sebesar :

$$
n=\frac{\mathbf{1 , 9 0}^{\mathbf{2}}}{\mathbf{4 ( \mathbf { 0 } , \mathbf { 1 } ) ^ { 2 }}}=90 \text { orang }
$$

(dibulatkan menjadi 100)

Sampel Penelitian. Sampel yaitu sebagian dari populasi yang diteliti. Sedangkan sampling yaitu cara pengumpulan data yang sifatnya tidak menyeluruh, artinya tidak mencakup seluruh obyek penelitian akan tetapi hanya sebagian dari populasi saja, yaitu hanya mencakup sampel yang diambil dari populasi tersebut (Supranto, 2003).

Teknik Pengambilan Sampel. Teknik pengambilan sampel dilakukan dengan menggunakan metode purposive sampling, yaitu teknik sampling yang digunakan peneliti jika peneliti mempunyai pertimbangan-pertimbangan tertentu di dalam pengambilan sampelnya atau penentuan sampel untuk tujuan tertentu. Kriteriakriteria yang dipakai dalam penelitian ini adalah sebagai berikut:

1. Berusia minimal 17 tahun,

2. Berbelanja pada Indomaret J1. Hayam Wuruk Purwodadi lebih dari 3 kali dalam waktu 6 bulan,

3. Bersedia memberikan informasi yang dibutuhkan.

Uji Validitas. Uji Validitas juga merupakan kemampuan dari indikatorindikator untuk mengukur tingkat keakuratan sebuah konsep. Artinya apakah konsep yang telah dibangun tersebut sudah valid atau belum. Uji ini melibatkan para ahli (ahli pemasaran, ahli statistik) dan pihak yang berkompeten (calon responden) untuk memberi komentar dan saran terhadap indikator yang dijabarkan dalam item pertanyaan (Sugiyono, 2012).

Uji Reliabilitas. Dalam pengujian ini, uji reliabilitas dilakukan dengan menggunakan koefisien alpha. Kalkulasi koefisien alpha memanfaatkan bantuan SPSS dan batas kritis untuk nilai alpha untuk mengindikasikan kuesioner yang reliabel adalah 0,70. Jadi nilai koefisien alpha $>0,70$ merupakan indikator bahwa kuesioner tersebut reliabel/handal.

Uji Analisis Data. Data yang diperoleh akan dianalisis dengan SPSS. Persamaan regresi linier berganda adalah sebagai berikut (Gujarati, 2001).

$$
Y=\beta_{1} X_{1}+\beta_{2} X_{2}+\beta_{3} X_{3}+e
$$

Dimana :

$$
\begin{aligned}
\mathrm{Y} & =\text { Kepuasan Konsumen } \\
\mathrm{X} 1 & =\text { Citra Perusahaan } \\
\mathrm{X} 2 & =\text { Persepsi Harga } \\
\mathrm{X} 3 & =\text { Kualitas Pelayanan } \\
\beta 1 \beta 2 \beta 3= & \text { Konstanta regresi dari masing- } \\
& \text { masing variabel independen } \\
\mathrm{E} & =\text { error }
\end{aligned}
$$

Uji t. Uji ini digunakan untuk melihat tingkat signifikan variabel independen mempengaruhi variabel dependen secara individu atau sendiri-sendiri. Pengkajian ini dilakukan secara persial atau individu, dengan menggunakan uji $\mathrm{t}$ statistik untuk masing-masing variabel bebas, dengan tingkat kepercayaan tertentu (Bawono, 2006).

Uji F ( Uji secara Simultan). Uji F diggunakan untuk menguji Uji $\mathrm{F}$ adalah alat untuk menguji kebenaran pengaruh variabel independen (X) terhadap variabel dependen(Y) secara bersama-sama sehingga dapat dibuktikan bahwa pengaruh yang didapat bukan suatu kebetulan belaka Sugiyono, (2009).

Uji $\mathbf{R}^{2} \quad$ (Koefisien Determinasi). Koefisien determinasi $\left(\mathrm{R}^{2}\right)$ menunjukkan sejauh mana tingkat hubungan antar variabel dependen ( $\mathrm{Y}$ ) dengan variabel independen $\left(\mathrm{X}_{1,2}\right)$, atau sejauh mana kontribusi variabel independen $\left(\mathrm{X}_{1,2}\right)$ mempengaruhi variabel dependen (Y).

Menurut Gujarati Analisis koefisien determinasi $\left(\mathrm{R}^{2}\right)$ digunakan untuk mengetahui seberapa besar prosentase (\%) pengaruh keseluruhan variabel independen 
yang digunakan $\left(\mathrm{X}_{1,2}\right)$ terhadap variabel dependen (Y). Pengujian ini dilakukan dengan melihat $\mathrm{R}^{2}$ pada hasil analisis persamaan regresi yang diperoleh. Apabila angka koefisien determinasi $\left(\mathrm{R}^{2}\right)$ semakin mendekati 1 berarti model regresi yang diigunakan sudah semakin tepat sebagai model penduga terhadap variabel dependen (Y).

\section{HASIL DAN PEMBAHASAN}

Uji Validitas Data. Setelah di Uji dengan alat bantu SPSS Versi 21.00 maka dapat diketahui valid dan tidaknya hasil dari jawaban kuesioner yang dibagikan kepada konsumen. Sedangkan hasil dari semua variabel Sesuai dengan hasil pengolahan data di atas menunjukkan bahwa semua butir angket telah memenuhi validitas penyusunan skor penelitian.

Uji Reliabilitas. Berdasarkan hasil perhitungan menggunakan SPSS dengan hasil uji reliabilitas yang dilakukan dengan menggunakan rumus Alpha Cronbach. Kriteria pengujian yang digunakan untuk menentukan reliabilitas didasarkan pada hasil koefisien reliabilitas dengan probabilitas 0,5 pada taraf signifikansi $5 \%$. maka instrumen penelitian tidak reliabel.

Hasil Analisa Data Analisis Regresi Linier Berganda. Analisis regresi linier berganda menggunakan keeratan hubungan variabel independen (citra perusahaan $\left(\mathrm{X}_{1}\right)$, persepsi harga $\left(\mathrm{X}_{2}\right)$ dan kualitas pelayanan $\left(\mathrm{X}_{3}\right)$ terhadap variabel dependen (kepuasan konsumen).

Model persamaan regresi linier berganda hasil penelitian yang didapat

$$
Y=0,254 X_{1}+0,029 X_{2}+0,551 X_{3}
$$

Dari analisa persamaan regresi linier berganda dapat diketahui bahwa besarnya untuk $\mathbf{0 , 2 5 4 b _ { 1 }}+\mathbf{0 , 0 2 9 b _ { 2 }}+\mathbf{0 , 5 5 1 b _ { 3 }}$ hal ini menunjukkan bahwa variabel yang paling berpengaruh adalah kualitas pelayanan yang memberikan pengaruh lebih besar dibanding dengan variabel yang lain yaitu citra perusahaan dan persepsi harga.

Uji-t (Pengujian Hipotesis). Pengujian koefisiensi regresi parsial
1. Koefisien regresi parsial citra perusahaan $\left(\mathrm{X}_{1}\right)$ terhadap kepuasan konsumen. Setelah dianalisis diperoleh nilai $t_{\text {hitung }} X_{1}(3,243)>t_{\text {tabel }}(1,990)$, maka Ho ditolak dan $\mathrm{Ha}$ diterima kesimpulan variabel citra perusahaan berpengaruh positif dan signifikan terhadap kepuasan konsumen

2. Koefisien regresi parsial persepsi harga $\left(\mathrm{X}_{2}\right)$ terhadap kepuasan konsumen. Setelah dianalisis diperoleh nilai $\mathrm{t}_{\text {hitung }}$ $\mathrm{X}_{2}(0.380)<\mathrm{t}_{\text {tabel }}(1,990)$, maka Ho diterima dan $\mathrm{Ha}$ ditolak kesimpulan variabel persepsi harga tidak berpengaruh positif dan tidak signifikan terhadap kepuasan konsumen.

3. Koefisien regresi parsial kualitas pelayanan $\left(\mathrm{X}_{3}\right)$ terhadap kepuasan konsumen. Setelah dianalisis diperoleh $t_{\text {hitung }}$ nilai $X_{3}(7.547)>t_{\text {tabel }}(1,990)$, maka Ho ditolak dan $\mathrm{Ha}$ diterima kesimpulan variabel kualitas pelayanan berpengaruh positif dan signifikan terhadap kepuasan konsumen.

Uji Secara Simultan (Uji F). Berdasarkan tabel diatas menunjukkan hasil perhitungan uji $\mathrm{F}$ diperoleh nilai $\mathrm{F}$ hitung sebesar 32,242 dengan tingkat signifikan sebesar $0,000<0,05$. Sementara nilai $F$ tabel sebesar 1,45. Hal ini berarti bahwa $\mathrm{F}$ hitung $(32,242)>\mathrm{F}$ tabel $(1.45)$.

Maka dapat disimpulkan bahwa secara simultan ada berpengaruh.

Koefisien Determinasi $\left(\mathbf{R}^{2}\right)$. Berdasarkan hasil perhitungan dengan menggunakan alat bantu program statistik SPSS 21.0 for windows dapat dijelaskan bahwa nilai koefisien determinasi $\left(\mathrm{R}^{2}\right)$ adalah sebesar 0,451 atau 45,1\%.

Hal ini berarti bahwa variabel independen (citra perusahaan, persepsi harga dan kualitas pelayanan) secara bersama-sama mempengaruhi variabel dependen. (kepuasan konsumen) sebesar 45,1\%. Sedangkan sisanya sebesar $54.9 \%$.

Variabel Citra Perusahaan $\left(\mathbf{X}_{1}\right)$. Variabel Citra Perusahaan ( $\mathrm{t}$ hitung $=3,243$ ) secara parsial berpengaruh positif dan signifikan terhadap kepuasan konsumen Indomaret Jl. Hayam Wuruk Purwodadi. Hal 
Tabel 1

Analisis Regresi Linier Berganda

\begin{tabular}{|c|c|c|c|c|c|c|}
\hline \multicolumn{7}{|c|}{ Coefficients $^{\mathrm{a}}$} \\
\hline & \multirow[t]{2}{*}{ Model } & \multicolumn{2}{|c|}{$\begin{array}{l}\text { Unstandardized } \\
\text { Coefficients }\end{array}$} & \multirow{2}{*}{$\begin{array}{c}\text { Standardized } \\
\text { Coefficients } \\
\text { Beta }\end{array}$} & \multirow[t]{2}{*}{$\mathrm{t}$} & \multirow[t]{2}{*}{ Sig. } \\
\hline & & B & Std. Error & & & \\
\hline \multirow[t]{4}{*}{1} & (Constant) & 3.756 & 2.998 & & 1.253 & .213 \\
\hline & CitraPerush & .226 & .070 & .254 & 3.243 & .002 \\
\hline & PersepsiHarga & .026 & .067 & .029 & .380 & .705 \\
\hline & KualitasPelay & .620 & .082 & .551 & 7.547 & .000 \\
\hline
\end{tabular}

a. Dependent Variable: Kepuasan Konsumen

Sumber : Olah data SPSS v.21

ini diperkuat dengan penelitian Maryati (2020), mengatakan pengaruh yang positif dan signifikan dari citra perusahaan terhadap kepuasan konsumen, Suratno, at. al, 2016, mengatakan bahwa ada pengaruh yang positif dan signifikan dari citra perusahaan terhadap kepuasan konsumen.

Variabel Persepsi Harga $\left(\mathbf{X}_{2}\right)$. Variabel persepsi harga (t hitung $=0,389)$ secara persial tidak berpengaruh positif terhadap kepuasan konsumen Indomaret Jl. Hayam Wuruk Purwodadi. Hal ini diperkuat dengan penelitian Cahya \& Shihab, (2018). dalam peneletiannya mengatakan bahwa persepsi harga tidak berpengaruh dan signifikan terhadap kepuasan konsumen.

Variabel Kualitas Pelayanan ( $\left.\mathbf{X}_{3}\right)$. Variabel kualitas pelayanan $\left(\mathrm{t}_{\text {hitung }}=7.547\right)$ secara persial berpengaruh positif dan signifikan terhadap kepuasan konsumen Indomaret Jl. Hayam Wuruk - Purwodadi. Hal ini diperkuat dengan penelitian Nuruddin, (2021) dalam penelitiannya menyimpulkan bahwa kualitas pelayanan berpengaruh terhadap kepuasan konsumen.

Penelitian yang dilakukan oleh Oktaviani et al (2021), dalam penelitiannya menyatakan kualitas pelayanan berpengaruh signifikan dan positif terhadap kepuasan konsumen.

\section{SIMPULAN}

Kesimpulan. Kesimpulan dari hasil penelitian bagi konsumen Indomaret $\mathrm{Jl}$. Hayam Wuruk Purwodadi. Citra perusahaan, persepsi harga dan kualitas pelayanan secara langsung berpengaruh positif dan signifikan terhadap kepuasan konsumen:

1. Citra perusahaan berpengaruh positif dan signifikan terhadap kepuasan konsumen pada konsumen Indomaret J1. Hayam Wuruk Purwodadi.

2. Persepsi harga tidak berpengaruh signifikan terhadap kepuasan konsumen pada konsumen Indomaret Jl. Hayam Wuruk Purwodadi.

3. Kualitas pelayanan berpengaruh positif dan signifikan terhadap kepuasan konsumen pada konsumen Indomaret Jl. Hayam Wuruk Purwodadi,

4. Uji determinasi pertama berdasarkan hasil uji koefisien determinasi $\left(\mathrm{R}^{2}\right)$ adalah sebesar 0,451 atau 45,1\%. Hal ini berarti bahwa variabel independen (citra perusahaan, persepsi harga dan kualitas pelayanan) secara bersama-sama mempengaruhi dependen variabel (kepuasa pelanggan) sebesar 59,1\%. Sedangkan sisanya sebesar $54.9 \%$.

5. Saran. Pihak Indomaret perlu meningkatkan kualitas pelayanan agar konsumen lebih merasa puas terhadap 
pelayanan yang diberikan seperti halnya pelayanan secara fisik dengan adanya mushola, WC umum dan tempat tongkrongan.

Dengan adanya fasilitas tersebut maka konsumen akan merasa lebih puas lagi untuk belanja di Indomaret. Diberikan pembelian produk melalui delivery.

Keterbatasan. Peneliti menyadari bahwa penelitian ini memiliki beberapa keterbatasan yang dapat mempengaruhi hasil penelitian yaitu kurangnya pemahaman dari responden terhadap pertanyaanpertanyaan dalam kuesioner serta sikap kepedulian dan keseriusan dalam menjawab semua pertanyaan-pertanyaan yang ada menjadi kendala dalam penelitian ini. Hal ini diakui oleh peneliti sebagai keterbatasan disebabkan karena peneliti tidak menggunakan metode wawancara secara mendalam dengan semua responden dalam penelitian ini.

Agenda Penelitian Mendatang. Untuk penelitian yang akan datang disarankan untuk menambah variabel lain dalam penelitian ini sehingga penelitiannya lebih baik lagi. Dengan mengambil subyek penelitian yang berbeda maka permasalahan yang dialami yaitu kepuasan konsumen yang dipengaruhi citra perusahaan, persepsi harga, dan kualitas pelayanan. Peneliti selanjutnya dapat dilakukan dengan melihat keterbatasan pada peneliti yaitu masih ada variabel-variabel perlu di masukkan sehingga peneliti menyarankan untuk menambah variabel-variabel lain sehingga penelitian berikutnya lebih sempurna lagi.

\section{DAFTAR PUSTAKA}

A.A Ayu at.al. 2013. Pengaruh Kualitas Layanan Terhadap Kepuasan Dan Loyalitas Pelanggan Garuda Indonesia Di Denpasar. Jurnal Manajemen, Strategi Bisnis, dan Kewirausahaan Vol. 7, No. 1, Februari 2013.

Adare, et al., 2014, Pengaruh Kualitas Produk, Harga dan Promosi Terhadap Kepuasan Pelanggan Kartu Prabayar Telkomsel. Jurnal EMBA, Vol.2 No.3. September 2014, Hal. 1237-1245.ISSN 2303-1174.
Ajeng Utami Ikasari, Sri Suryoko, \& Sendhang Nurseto. 2013 Pengaruh Nilai Pelanggan Dan Kualitas Pelayanan Terhadap Kepuasan Pelanggan (Studi kasus pada penumpang KA Kaligung Mas di Stasiun Poncol Semarang). DIPONEGORO JOURNAL OF SOCIAL AND POLITIC Tahun 2013, Hal. 1-8 http://ejournals1. undip.ac.id/index.php/

Amstrong, K. \&. (2001). Prinsip-Prinsip Pemasaran. Jakarta: Erlangga.

Bawono, Anton. 2006. Multivariate Analysis dengan SPSS. Salatiga: STAIN Salatiga press.

Bowen, J. T. and Chen, S. 2001. "The Relationship between Customer Loyalty and Customer Satisfaction," International Journal ofContemporary Hospitality Management, 13 (5):213-217.

Buchari Alma. 2009. Manajemen Pemasaran dan Pemasaran Jasa. Bandung : PT. Alfabeta.

C. Mowen, John dan Michael Minor. 2002. Perilaku Konsumen. Jakarta : Erlangga.

Cannon, Joseph P., William D. Perreault Jr. dan Jerome McCarthy. 2008. Alih Bahasa : Diana Angelica dan Ria Cahyani. Pemasaran Dasar-Dasar : Pendekatan Manajerial Global. Buku 2. Edisi 16. Salemba Empat. Jakarta.

Cronin, J. Joseph, Jr and Steven A. Taylor. 2002. Measuring Service Quality: A Reexamination and Extention, Journal of Marketing Vol. 56, 55-58.

Danang Sunyoto. 2013. Dasar-Dasar Manajemen Pemasaran. Yogyakarta: CAPS

Day (1969) and Jarvis et al., 1976; Pritchard 1991). Cognitive Loyalty. Lee dan Zeiss,( 1980 ) dimension behavior.

Djaslim, Saladin. 2003. Manajemen Pemasaran, Analisis Perencanaan Pelaksanaan dan Pengendalian. Bandung.

Edi Supriad, Oktaviani1, Zulkifli2, Edi Supriadi 2021 Analisis Strategi Citra Merek Dalam Meningkatkan Kepuasan Pelanggan Octo Mobile e-ISSN: 2722-0273 p-ISSN: 27220281. Jurnal Akuntansi AKTIVA, Vol. 2, No. 1, April 2021

Edy Haryanto,.2013. Kualitas Layanan, Fasilitas Dan Harga Pengaruhnya Terhadap Kepuasan Pengguna Jasa Layanan Pada Kantor Samsat Manado. Jurnal EMBA Vol.1 No.3 September 2013, Hal. 750-760. (Fakultas Ekonomi dan Bisnis Program 
Pasca Sarjana, Magister Manajemen Universitas Sam Ratulangi Manado)

Fandy Tjiptono, 2002. Manajemen Pelayanan Jasa. Yogyakarta.

Fandy Tjiptono, 2007. Prinsip-prinsip Total Quality Service.

Fathoni. at. al 2016. Analisis Faktor-Faktor Yang Mempengaruhi Kepuasan Pelanggan Di Perusahaan Galangan Kapal (Studi Kasus Pada Pt. Janata Marina Indah Semarang). Journal of Management, Volume 2 No. 2 Maret 2016.

Giese \& Cote.(2000). Academy of Marketing Science Review.Defining Consumer Satisfaction. Vol 2000 No. 1 Available :http://www.amsreview.org/articlesgiese012000.pdf

Ginting,Nembah F. Hartimbul. 2012. Manajemen Pemasaran. Cetakan 2. Bandung: Yrama Widya.

Gujarati, Damodar N dan Porter, Dawn C. 20011 "Dasar-Dasar Ekonometrika". Selemba Empat, Jakarta.

IIndra Lutfi Sofyan, Ari Pradhanawati \& Hari Susanta Nugraha. Pengaruh Fasilitas dan Kualitas Pelayanan Terhadap Loyalitas, Melalui Kepuasan Konsumen Sebagai Variabel Intervening pada Star Clean Car Wash Semarang. DIPONEGORO JOURNAL OF SOCIAL AND POLITIC Tahun 2013, Hal. 1-12 http://ejournals1. undip.ac.id/index.php/

Jasfar, F. 2005. Manajemen Jasa manajemen Terpadu. Bogor: Ghalia Indonesia.

Kotler, P. dan Keller, K.L. 2009.Manajemen Pemasaran, edisi ketiga belas. Jakarta: Erlangga. Kotler. 2005. Manajemen Pemasaran. Edisi Kesebelas. Jakarta : PT Indeks Kelompok Gramedia.

Kotler, Philip. (2000). Marketing Management, The Millenium Edition, Internatioal Edition. New Jersey: Prentice Hall International Inc.,

Kotler, Philip. dan Gary Armstrong. 2004. Prinsip prinsip Pemasaran.

Kuncoro, Mudrajad. 2009. Metode Riset untuk Bisnis dan Ekonomi. Edisi 3. Penerbit Erlangga.

Lupiyoadi 2008. Manajemen Pemasaran Jasa, Teori \& Praktik.. Jakarta: Salemba Empat.
Lupiyoadi, Rambat dan Hamdani, 2006. Manajemen Pemasaran Jasa. Jakarta: Salemba Empat.

Mahmud. Nuruddin 2021 Pengaruh Harga, Kualitas Produk Dan Kualitas Pelayanan Terhadap

Kepuasan Pelanggan Di Transmart Setiabudi Semarang Vol 3, No 1, pp 159167. April 2021. E-ISSN: 2746-1173, PISSN: 2085-773. . Jurnal Ekonomi dan Bisnis STIE Anindyaguna.

Maryati, Nana Darna, Ali Muhidin 2020. Pengaruh Citra Perusahan Dan Kualitas Layanan Terhadap Kepuasn Konsumen (Studi pada PD. Sumber Rezeki Singaparna) Busines manajemen, and interprenuership Jurnal Volume 2 | Nomor 2 Juni 2020. Fakultas Ekonomi Universitas Galuh

Oktaviani1, Zulkifli2, Edi Supriadi 2021. Analisis Strategi Citra Merek Dalam Meningkatkan Kepuasan Pelanggan Octo Mobile Jurnal Akuntansi AKTIVA, Vol. 2, No. 1, April 2021

Peter, J. Paul and Jerry C. Olson. 2014. Perilaku Konsumen dan Strategi Pemasaran. Andi. Yogyakarta

R. Gulla., S. G. Oroh., F. Roring 2015 Analisis Harga, Promosi, Dan Kualitas Pelayanan Terhadap Kepuasan Konsumen Pada Hotel Manado Grace Inn. (Fakultas Ekonomi dan Bisnis Jurusan Manajemen Universitas Sam Ratulangi Manado) Jurnal EMBA Vol.3 No.1 Maret 2015, Hal.1313-1322

Rochyan Ridlo Rien Rizqy, Moh. Mukeri Warso, Aziz Fathoni.. 2016. Pengaruh Kualitas Pelayanan Terhadap Kepuasan Konsumen (Studi Kasus pada Konsumen PT. Graha Service Indonesia Cabang Semarang). Journal Of Management, Volume 2 No. 2 Maret 2016.

Saputra, at al. 2017. Pengaruh Harga, Promosi, Dan Kualitas Pelayanan Terhadap Kepuasan Pelanggan (Studi Pada Bengkel Ahass 0002 Astra Motor Siliwangi Semarang.

Schiffman dan Kanuk, 2007. "Perilaku Konsumen". Edisi Kedua. Jakarta : PT. Indeks Gramedia

Stephen L. Sondoh Jr, Maznah Wan Omar, Nabsiah Abdul Wahid, Ishak Ismail, and Amran Harun, 2007. The Effect of Brand 
Image on Overall Satisfaction and Loyalty Intention In The Context of Color Cosmetic, Asian Academy of Management Journal, Vol 12 (83-107).

Suratno, at.al. 2016). Pengaruh Citra Perusahaan Dan Kualitas Pelayanan Terhadap Loyalitas Pelanggan Dengan Kepuasan Pelanggan Sebagai Variabel Intervening Pada $\mathrm{Pt}$ Pelabuhan Indonesia Iii Semarang. Journal
Of Management, Volume 2 No.2 Maret 2016.

Swastha, Basu. 2001. Pengantar Bisnis Modern, Edisi Ketiga, Penerbit Liberty.

Yengki Eka Wijaya \& Okta Karneli. 2017 Pengaruh Diversifikasi Produk Dan Harga Terhadap Kepuasan Pelanggan (Studi Pada Pelanggan Kentucky Fried Chicken (KFC) Metropolitan City Pekanbaru). JOM FISIP Vol. 4 No. 2 - Oktober 2017. 